\author{
Professor Anca-Otilia DODESCU, PhD \\ E-mail: adodescu@uoradea.ro \\ Professor Elena-Aurelia BOTEZAT, PhD \\ E-mail: ebotezat@uoradea.ro \\ Associate Professor Alexandru COSTĂNGIOARĂ, PhD \\ E-mail: aconstangioara@uoradea.ro \\ Professor Marcel-Ioan BOLOS, PhD \\ E-mail: mbolos@uoradea.ro \\ University of Oradea
}

\title{
AN EXPLORATORY ANALYSIS OF THE TERRITORIAL CAPITAL AND ECONOMIC GROWTH: EVIDENCE FROM ROMANIA
}

\begin{abstract}
The paper investigates Romanian territorial capital components and analyses the relationship between them and economic growth using structural equation modeling methodology (SEM). The available dataset across Romanian counties (NUTS 3) offered by national statistics allows for identifying five components of territorial capital: economic, infrastructural, institutional, human and social capital. Our research reveals that four components - economic, infrastructural, institutional and human capital - are contributing positively to the Romanian territorial capital and one - social capital - has a negative impact. Also, we found that not all the components of the Romanian territorial capital positively influenced economic growth. The findings document a positive impact of economic and infrastructural capital, a negative impact of social capital and an insignificant impact of human capital and institutional capital on economic growth. In our opinion, all these findings have important development policy implications and urging for future research.
\end{abstract}

Keywords: territorial capital, economic growth, economic development, structural equation modeling (SEM), Romania

JEL Classification: R11, 040.

1. Introduction

Defined as a system of economic, social, cultural, institutional and environmental assets that constitute the 'dowry' of the given area, the concept of 
Anca Dodescu, Elena-Aurelia Botezat, Alexandru Costăngioară, Marcel-Ioan Bolos

territorial capital, launched by the OECD in 2001 [19], is increasingly recognized as a driver of economic growth due to its intangible elements, that 'something in the air' as Marshall described, that makes 'a certain creativity and innovation possible' [19] (p. 15).

Building upon existing literature in the field, this article constructs a model for Romanian territorial capital, investigates its factors and analyses the relationship between them and economic growth. The data on which the article relies consists of secondary data assembled from the Territorial Statistics 2015, the last publication of the Romanian National Institute of Statistics (RNIS) [20].

The paper is structured as follows: Section 2 provides an analysis of theoretical background of the territorial capital and its connection with economic growth and regional development in order to formulate research hypothesis, Section 3 considers the methodology of research used to address the research hypothesis, Section 4 discusses the results of the research and Section 5 summarizes and concludes the paper.

\section{Territorial Capital and Economic Growth and Development:}

\section{Theoretical Background and Research Hypothesis}

Since 1950, in the economic literature, different factors have been considered one by one as being decisive for economic growth and development: infrastructure, industrial specialization, exports, central locations, production factors, growth poles, economic agglomerations, SMEs and local competences, technological diffusion and innovation, knowledge bases, intangible factors, local culture, relationships, partnerships and networks, territorial capital etc. $[8,10,11$, 12]. Currently, as Capello and Nijkamp have shown, there is a need for a 'convincing model' that should demonstrate 'the territorial micro-foundations of macroeconomic models of growth' [11] (p. 8).

The territorial capital is closest to that 'convincing model' but its conceptual and operational area requires a multidisciplinary approach able to reduce deficiencies in the conceptual analysis, classification systems, methodologies for collecting and comparing data.

From this perspective, Camagni's approach $(2008,2009)$ is the most comprehensive $[6,7]$. Seen as a system of localized elements such as: pecuniary and technological externalities; production activities, traditions, skills and know-hows; proximity relationships; cultural elements and values; rules and practices [7] (p. 
An Exploratory Analysis of the Territorial Capital and Economic Growth: Evidence from Romania

120) - Camagni's territorial capital includes a large variety of territorial goods classified not only on materiality (tangible and intangible) but also on rivalry (public and private) and placed in a 'three-by-three matrix' highlighting in the corners the so-called 'traditional square', respectively the 'innovative cross' in the middle [7] (pp. 121-122).

According with Capello, Caragliu and Nijkamp (2009) [10], in the corners of the Camagni's territorial capital matrix are the elements 'easiest to identify' (physical capital, labour, infrastructure, social capital) that 'can enter directly into a traditional production function' (private tangible goods: fixed capital stock, hard pecuniary externalities, toll goods; public tangible goods: natural and cultural resources, social overhead capital - infrastructure; public intangible goods: collective action; private intangible goods: human capital, soft pecuniary externalities). By contrast, the elements on the cross are difficult to identify, characterized by 'less sharply defined boundaries' (knowledge creation, knowledge exploitation, combination of physical factors) and form the glue of a society, stemming from complex cognitive processes that are cumulated in a society over time' (impure public-private tangible or hard goods: proprietary networks, collective goods such as landscape, cultural heritage; impure public-private intangible or soft goods: relational capital; mixed goods - public+private and hard+soft: relational private services, university spin-offs, cooperation networks, governance of land and cultural resources, agencies for R\&D transfer, receptivity enhancing tools, connectivity, agglomeration and district economies) [10].

Starting from Camagni's approach, the model of territorial capital includes several types of capital: natural, environmental, anthropic, infrastructural, economic, human, institutional, social, cultural, relational. Different scholars looking for appropriate indicators in the case of measurement of territorial capital components $[5-10,14]$, the number and grouping of territorial capital components and indicators used varies from one author to another. Also, due to the relevance of the model of territorial capital as theoretical framework for EU regional development policy, a lot of organizations and projects researched the most appropriate indicators and indices for individual assets of the certain capital which can be attached to territorial objectives that meet both Territorial Agenda 2020 and Europe 2020 Strategy priorities [4, 8, 22]. 
Anca Dodescu, Elena-Aurelia Botezat, Alexandru Costăngioară, Marcel-Ioan Bolos

A very clear synthesis of the most representative approaches in literature regarding the components of territorial capital belongs to Jona (2015) [14]: economic capital (the economic performance of the region), infrastructural capital (the aptness and size of the elements of infrastructure), institutional capital (the public institutions and their services), human capital (the health condition of the population and the region's knowledge level), social capital (the level of social integration: employment and local social inequalities), relational capital (the communicational devices), cultural capital (the cultural institutions and their capacity).

EU Member States are characterized by very different endowments of territorial capital. Given the difficulties in the collection of data at the national level and similarities between Romania and Hungary in terms of national statistics, we considered relevant for our analysis Jona's approach (2015) [14]. The available dataset across Romanian counties (NUTS 3) offered by national statistics [20] allows for identifying 5 major components of territorial capital: economic, infrastructural, institutional, human and social capital. Consequently, Romanian territorial capital is a second order latent construct. Its factors are in their turn latent variables, with indicator variables presented in Table 1.

Table 1. Variables constructing territorial capital

\begin{tabular}{|l|l|}
\hline Factor & Indicator variables \\
\hline Economic capital & Number of active firms \\
\cline { 2 - 2 } & Sales \\
\cline { 2 - 2 } & Gross investment \\
\cline { 2 - 2 } & Net investment \\
\cline { 2 - 2 } & Employees \\
\hline Infrastructural capital & Density of public roads \\
\cline { 2 - 2 } & Density of rail roads \\
\cline { 2 - 2 } & Volume of distributed water \\
\cline { 2 - 2 } & Internet connections \\
\hline & Number of libraries \\
\cline { 2 - 2 } & Number of hospital beds \\
\cline { 2 - 2 } & Number of hospitals \\
\cline { 2 - 2 } & Number of polyclinics \\
\hline
\end{tabular}


An Exploratory Analysis of the Territorial Capital and Economic Growth: Evidence from Romania

\begin{tabular}{|l|l|}
\hline \multirow{5}{*}{ Human capital } & Number of dispensaries \\
\cline { 2 - 3 } & Number of medical offices \\
\cline { 2 - 2 } & Number of dentist offices \\
\cline { 2 - 2 } & Number of pharmacies \\
\hline & Live births \\
\cline { 2 - 3 } & Death under one year old \\
\hline & Number of physicians \\
\hline & Number of dentists \\
\hline & Number of pharmacists \\
\hline & Number of medical personnel \\
\hline & Number of general school graduates \\
\hline & Number of high school graduates \\
\hline & Number of college graduates \\
\hline & Number of university graduates \\
\hline & Educators in kindergartens \\
\hline & Teachers in primary schools \\
\hline & Teachers in high-schools \\
\hline & Teachers in colleges \\
\hline & Teachers in universities \\
\hline Social capital & Unemployment \\
\hline Social benefits \\
\hline Net migration \\
\hline Number of welfare recipients \\
\hline Number of crimes investigated \\
\hline
\end{tabular}

Source: the work of authors based on available dataset across Romanian counties (NUTS 3) [20]

An examination of the relationship between the Romanian territorial capital and its components allows us to test the first hypothesis of this research:

Hypothesis 1: Each capital type is positively, statistically and significantly correlated with the territorial capital.

The concept of territorial capital, as Camagni (2009) [7] shows, summarizes the endogenous sources of economic growth and provides a solid, homogenous theoretical framework through which present development scenarios can be 
Anca Dodescu, Elena-Aurelia Botezat, Alexandru Costăngioară, Marcel-Ioan Bolos

explained and policy implication can be identified. Consequently, we formulate the second research hypothesis:

Hypothesis 2: There is a positive and statistical significant relationship between territorial capital and economic growth.

\section{Methodology}

Following recommendations in existing literature on territorial capital, our research employs the structural equations methodology (SEM). As indicated by Sechi et al. (2012) [21], SEM is the most prevalent research methodology employed by empirical studies for complex relationships involving latent variables. With SEM, the measurement of unobserved (latent) variables by indicator variables can be modeled explicitly. As opposed to analysis based on OLS, SEM also allows for estimating multiple equations, correlated errors, direct and indirect effects, latent variables, parametric constraints and multiple group analysis.

In what follows we present the general framework of SEM, as well as the identification and estimation issues which arise in practice, motivating our choices for the purposes of current analysis.

Formally, a system of $\mathrm{M}$ structural equations is described by:

(1) $[\mathrm{yt} 1, \mathrm{yt} 2, \ldots, \mathrm{ytM}][\gamma .1, \gamma .2, \ldots, \gamma . \mathrm{M}]+\mathrm{xt} .[\beta .1, \beta .2, \ldots \beta . \mathrm{M}]+[\varepsilon \mathrm{t} 1+\varepsilon \mathrm{t} 2+\ldots . . \mathrm{\varepsilon tM}]$ $=[0,0, \ldots, 0]$.

In summary notation the system is depicted by:

(2) yt. $\Gamma+\mathrm{xt} . \mathrm{B}+\varepsilon \mathrm{t} .=0$, where $\Gamma=[\gamma .1, \gamma .2, \ldots, \gamma . \mathrm{M}]$.

Structural disturbances (\&t) are assumed to be distributed independently of time and of exogenous variables, which means:

(3) $\mathrm{E}(\varepsilon t)=0,. \mathrm{D}(\varepsilon t)=.\mathrm{E}\left(\varepsilon^{\prime}\right.$ t. $\left.\left.\varepsilon \mathrm{t}.\right)=\sum \varepsilon \varepsilon\right)$ and $\mathrm{C}(\varepsilon t ., \mathrm{xs})=$.0 for all $\mathrm{t}$ and $\mathrm{s}$.

The reduced form of the system is:

(4) $\mathrm{yt} .=\mathrm{xt} . \prod+\eta \mathrm{t}$. with $\prod=-\mathrm{B} \Gamma-1$.

And reduced formed disturbances:

(5) $\eta \mathrm{t} .=-\varepsilon t . \Gamma-1 \quad$ with $\mathrm{E}(\eta \mathrm{t})=$.0 and $\mathrm{D}(\eta \mathrm{t})=.\Gamma^{\prime}-1 \mathrm{D}(\varepsilon t$. $) \Gamma-1=\Gamma^{\prime}-1 \sum \varepsilon \varepsilon \Gamma-1=\Omega$.

In practice, for model identification it is necessary to have for each free parameter at least one solution, otherwise the parameter is unidentified. Moreover, model as a whole must be identified; meaning the number of estimated parameters must not exceed total number of observed variances and covariances. For model estimation, SEM uses iterative estimation methods. Start values are generally supplied by a two-stage least squares procedure (2SLS). Model estimation relies most often on maximum likelihood estimations (ML), although other methods are 
An Exploratory Analysis of the Territorial Capital and Economic Growth: Evidence from Romania

available. The existing literature in the field, through Marsh, Hau and Wen (2004) recommends in particular using the asymptotically distribution free (ADF) or bootstrapping when robustness of data is an issue [17].

For SEM estimation there are many software packages available. First SEM software, the linear structural relations model (LISREL) was developed by Jöreskog (1972) [15], Keesling (1972) [16] and Wiley (1972) [23]. Today, besides LISREL, most prevalent in empirical studies based on SEM methodology are AMOS, EQS, MPLUS or PROC CALIS.

We have chosen the later one (available with SAS 9.3 statistical package), for its ability to tackle the intricacies and complexity of the issues specific to SEM.

Not ultimately, existing literature on SEM, has come to consider today PROC CALIS as a synonym of SEM [25], adding to our motivation for employing SEM in present research. Moreover, PROC CALIS supports more modelling languages. We have chosen to employ the Path modelling language. Developed by Wright (1934) [24], path diagrams, like flowcharts, provide a graphical representation of the causality relationships among variables. In addition, different extensions of the path analysis cover all major applications of SEM. Thus Yung (2010) [25] shows that PATH can be employed in the case of (a) confirmatory factor analysis which tests a particular structure of the factors, (b) second order factor analysis, where second order factors are being developed from the correlation matrix of initial factors, (c) covariance structure models which hypothesizes a particular form of the covariance matrix and, not ultimately for (d) correlation structure matrix where the focus relies on testing a particular correlation matrix.

All these applications are employed in socio-economical, including territorial capital empirical studies, educational, behavioral and marketing research.

Not ultimately, we have chosen PROC CALIS because of its ability to supply multiples fit indexes, enhancing our ability to adequately evaluate the model fit and adequate measures of model's fit Yung (2010) [25], Marsh, Hau and Wen (2004) [17], McDonald and Ho (2002) [18].

Following Albu (1998), the adequacy of the measurement model was assessed through an examination of the (a) content validity, (b) substantive validity, (c) unidimensionality and (d) reliability for each construct employed in the analysis [1]. 
Anca Dodescu, Elena-Aurelia Botezat, Alexandru Costăngioară, Marcel-Ioan Bolos

As required by similar studies [5-7, 10, 14, 22], we first conducted a throughout review of existing literature in search of adequate measurement scales, ensuring the substantive and content validity of the scales. Consequently, the scales used in the analysis measure all facets of the underlying theoretical concepts and all the items are being conceptually and theoretically linked to the construct. Unidimensionality of a scale is 'the degree to which items load only on their respective constructs' [13]. As opposed to principal components analysis which does not offer standard errors corresponding to estimated factor loadings, SEM offers standard errors and their corresponding t-values. Reliability is the overall consistency of a scale measure. A measure of reliability is given by Cronbach's $\alpha$.

In the second stage we have conducted a confirmatory factor analysis (CFA) using SEM apparatus. CFA is the analysis allowing for an explicit testing of the model and its hypothesis.

The proposed empirical research uses a dataset concerning territorial capital across Romanian counties corresponding to the year 2012 or 2012/2013 (especially for human capital). The dataset was assembled from the Territorial Statistics 2015 [20], and one of our concerns was related to disponibility and comparability of data.

In order to test unidimensionality and reliability of the scales we rely on existing empirical studies in the field to propose the structural equations modelling.

Our choice for structural modelling was motivated by its advantages over more conventional methods such an OLS or Principal Component Analysis. Structural equation modelling is more efficient in evaluating the model fit. Moreover, as indicated by Yung (2010) [25], simple regression and factor analysis are of limited use for estimating multiple equations, correlated errors, direct and indirect effects, latent variables and multiple group analysis. For all its advantages structural equation modeling is best suited for analyzing the complex research framework proposed in this paper.

Model fit statistics and the results for the analysis of unidimensionality and reliability of scales are presented in Tables no. 2-6.

As shown in Table 2, the scale used to measure economic capital is unidimensional. All estimates are highly statistically significant. In addition the scale is also reliable with a Cronbach's $\alpha$ of 0.99 . 
An Exploratory Analysis of the Territorial Capital and Economic Growth: Evidence from Romania

Table 2. Economic capital. Analysis of the measurement scale

\begin{tabular}{|l|l|l|l|}
\hline Path & Estimate & Standard Error & t Value \\
\hline Number of active firms & 0.997 & 0.000 & 1.696 .000 \\
\hline Sales & 0.991 & 0.001 & 547.787 \\
\hline Gross investment & 0.982 & 0.003 & 247.435 \\
\hline Net investment & 0.984 & 0.003 & 294.649 \\
\hline Employees & 0.996 & 0.000 & 1.314 .000 \\
\hline
\end{tabular}

Source: the work of authors based on available dataset across Romanian counties (NUTS 3) [20]

According to Table 3, 'infrastructural capital' is measured initially using four indicator variables. However one of the estimates is not statistically significant. Consequently, final scale retains only three indicator variables: 'Density of rail roads', 'Volume of distributed water' and 'Internet connections'. The scale is reliable with a Cronbach's $\alpha$ close to 0.8 .

Table 3. Infrastructural capital. Analysis of the measurement scale

\begin{tabular}{|l|l|l|l|}
\hline Path & Estimate & Standard Error & t Value \\
\hline Density of public roads & 0.122 & 0.156 & 0.779 \\
\hline Density of rail roads & 0.907 & 0.029 & 31.069 \\
\hline Volume of distributed water & 0.906 & 0.022 & 40.757 \\
\hline Internet connections & 1.014 & 0.011 & 86.222 \\
\hline
\end{tabular}

Source: the work of authors based on available dataset across Romanian counties (NUTS 3) [20]

Institutional capital is adequately measured using eight indicator variables presented in Table 4. All estimates are positive and statistically significant and model fit is also good (Cronbach's $\alpha=0.95$ ).

Table 4. Institutional capital. Analysis of the measurement scale

\begin{tabular}{|l|l|l|l|}
\hline Path & Estimate & Standard Error & t Value \\
\hline Number of libraries & 0.552 & 0.109 & 5.062 \\
\hline Number of hospital beds & 0.993 & 0.001 & 687.033 \\
\hline Number of hospitals & 0.881 & 0.035 & 24.868 \\
\hline Number of polyclinics & 0.751 & 0.068 & 10.950 \\
\hline Number of dispensaries & 0.888 & 0.033 & 26.605 \\
\hline Number of medical offices & 0.962 & 0.008 & 113.331 \\
\hline
\end{tabular}


Anca Dodescu, Elena-Aurelia Botezat, Alexandru Costăngioară, Marcel-Ioan Bolos

\begin{tabular}{|l|l|l|l|}
\hline Number of dentist offices & 0.983 & 0.005 & 166.107 \\
\hline Number of pharmacies & 0.953 & 0.014 & 65.899 \\
\hline
\end{tabular}

Source: the work of authors based on available dataset across Romanian counties (NUTS 3) [20]

As shown in Table 5, the scale used to measure human capital uses eleven indicator variables. Estimates and their standard errors show that the scale is unidimensional. All estimates are highly statistically significant. In addition the scale is also reliable with a Cronbach's $\alpha$ of 0.98 .

Table 5. Human capital. Analysis of the measurement scale

\begin{tabular}{|l|l|l|l|}
\hline Path & Estimate & Standard Error & t Value \\
\hline Live births & 0.972 & 0.006 & 157.512 \\
\hline Death under one year old & 0.558 & 0.107 & 5.171 \\
\hline Number of physicians & 0.977 & 0.005 & 194.063 \\
\hline Number of dentists & 0.984 & 0.005 & 181.405 \\
\hline Number of pharmacists & 0.963 & 0.008 & 116.741 \\
\hline Number of medical personnel & 0.985 & 0.003 & 307.939 \\
\hline Number of general school graduates & 0.871 & 0.029 & 29.486 \\
\hline Number of high school graduates & 0.925 & 0.017 & 54.407 \\
\hline Number of college graduates & 0.851 & 0.034 & 24.824 \\
\hline Number of university graduates & 0.955 & 0.009 & 96.284 \\
\hline Educators in kindergartens & 0.950 & 0.011 & 85.558 \\
\hline Teachers in primary schools & 0.911 & 0.020 & 45.278 \\
\hline Teachers in high-schools & 0.955 & 0.010 & 95.563 \\
\hline Teachers in colleges & 0.615 & 0.097 & 6.320 \\
\hline Teachers in universities & 0.958 & 0.009 & 103.649 \\
\hline
\end{tabular}

Source: the work of authors based on available dataset across Romanian counties (NUTS 3) [20]

Table 6 presents the analysis of the measurement scale corresponding to social capital. Analysis included five indicator variables. Not all the estimates are statistically significant. Consequently `net migration` and `number of welfare recipients`were excluded from subsequent analysis. 
An Exploratory Analysis of the Territorial Capital and Economic Growth: Evidence from Romania

Table 6. Social capital. Analysis of the measurement scale

\begin{tabular}{|l|l|l|l|}
\hline Path & Estimate & Standard Error & t Value \\
\hline Unemployment & 0.723 & 0.092 & 7.790 \\
\hline Social benefits & 0.939 & 0.015 & 62.522 \\
\hline Net migration & 0.232 & 0.168 & 1.377 \\
\hline Number of welfare recipients & -0.125 & 0.177 & -0.710 \\
\hline Number of crimes investigates & 0.063 & 0.008 & 7.317 \\
\hline
\end{tabular}

Source: the work of authors based on available dataset across Romanian counties (NUTS 3) [20]

\section{Results and discussion}

Following Jona (2015) [14], we examined which capital types have determined the territorial capital in Romania. We generated factor scores and then we performed a structural equation modelling the relationship between the second order construct 'territorial capital' and its components. Results are presented in Table 7.

Table 7. Standardized results for path list

\begin{tabular}{|l|c|l|l|l|l|}
\hline \multicolumn{2}{|l|}{ Path } & Estimate & $\begin{array}{l}\text { Standard } \\
\text { Error }\end{array}$ & t Value \\
\hline Economic capital & $<---$ & $\begin{array}{l}\text { Territorial } \\
\text { capital }\end{array}$ & 0.935 & 0.021 & 43.105 \\
\hline $\begin{array}{l}\text { Infrastructural } \\
\text { capital }\end{array}$ & $<---$ & $\begin{array}{l}\text { Territorial } \\
\text { capital }\end{array}$ & 0.709 & 0.084 & 8.383 \\
\hline Institutional capital & $<---$ & $\begin{array}{l}\text { Territorial } \\
\text { capital }\end{array}$ & 1.003 & 0.004 & 212.416 \\
\hline Human capital & $<--$ & $\begin{array}{l}\text { Territorial } \\
\text { capital }\end{array}$ & 0.982 & 0.007 & 132.293 \\
\hline Social capital & $<---$ & $\begin{array}{l}\text { Territorial } \\
\text { capital }\end{array}$ & -0.603 & 0.108 & -5.568 \\
\hline
\end{tabular}

Source: the work of authors based on available dataset across Romanian counties (NUTS 3) [20]

Table 7 reveals that not all the components of the territorial capital are positively related to the underlying concept they are measuring. We see that based on our available data: 
Anca Dodescu, Elena-Aurelia Botezat, Alexandru Costăngioară, Marcel-Ioan Bolos

- $\quad$ social capital has a negative and statistically significant impact on territorial capital;

- the other four components (economic, infrastructural, institutional and human capital) are contributing positively to territorial capital.

In addition, we see that the estimated coefficient shows that the largest contribution to territorial capital is provided by:

1. institutional capital $(\alpha=1.00)$,

2. human capital $(\alpha=0.98)$,

3. economic capital $(\alpha=0.93)$.

In order to evaluate the possible positive spillovers from interactions among different components of territorial capital, we also estimated the standardized covariances among exogenous variables (Table 8).

Table 8. Standardized results for covariances among exogenous variables

\begin{tabular}{|l|l|l|l|l|}
\hline Var1 & Var2 & Estimate & $\begin{array}{l}\text { Standard } \\
\text { Error }\end{array}$ & t Value \\
\hline $\begin{array}{l}\text { Infrastructural } \\
\text { capital }\end{array}$ & Economic capital & 0.747 & 0.075 & 9.898 \\
\hline Human capital & Economic capital & 0.910 & 0.029 & 31.221 \\
\hline Human capital & $\begin{array}{l}\text { Infrastructural } \\
\text { capital }\end{array}$ & 0.670 & 0.094 & 7.107 \\
\hline Institutional capital & Economic capital & 0.939 & 0.020 & 46.548 \\
\hline Institutional capital & $\begin{array}{l}\text { Infrastructural } \\
\text { capital }\end{array}$ & 0.712 & 0.084 & 8.441 \\
\hline Institutional capital & Human capital & 0.985 & 0.004 & 199.918 \\
\hline Social capital & Economic capital & -0.719 & 0.082 & -8.681 \\
\hline Social capital & $\begin{array}{l}\text { Infrastructural } \\
\text { capital }\end{array}$ & -0.640 & 0.101 & -6.339 \\
\hline Social capital & Human capital & -0.608 & 0.108 & -5.633 \\
\hline Social capital & Institutional capital & -0.620 & 0.105 & -5.874 \\
\hline
\end{tabular}

Source: the work of authors based on available dataset across Romanian counties

(NUTS 3) [20] 
An Exploratory Analysis of the Territorial Capital and Economic Growth: Evidence from Romania

Indeed, as anticipated by the results in Table no. 8 , we see that social capital is negatively associated with the other components of territorial capital. To conclude:

- Hypothesis 1: 'Each capital type is positively, statistically and significantly correlated with territorial capital' is thus not confirmed.

In order to estimate the relationship between the territorial capital and economic growth, according to Hypothesis 2, we also use the structural equations approach. Results are presented in Table 9.

Table 9. Standardized results for covariances among exogenous variables

\begin{tabular}{|l|l|l|l|l|l|}
\hline \multicolumn{2}{|l|}{ Path } & Estimate & $\begin{array}{l}\text { Standard } \\
\text { Error }\end{array}$ & $\begin{array}{l}\text { t } \\
\text { Value }\end{array}$ \\
\hline Social capital & $--->$ & $\begin{array}{l}\text { economic } \\
\text { growth }\end{array}$ & -0.25 & 0.09 & -2.66 \\
\hline human capital & $--->$ & $\begin{array}{l}\text { economic } \\
\text { growth }\end{array}$ & -0.10 & 0.38 & -0.27 \\
\hline institutional capital & $--->$ & $\begin{array}{l}\text { economic } \\
\text { growth }\end{array}$ & -0.22 & 0.46 & -0.48 \\
\hline $\begin{array}{l}\text { infrastructural } \\
\text { capital }\end{array}$ & $--->$ & $\begin{array}{l}\text { economic } \\
\text { growth }\end{array}$ & 0.29 & 0.09 & 3.05 \\
\hline economic capital & $--->$ & $\begin{array}{l}\text { economic } \\
\text { growth }\end{array}$ & 0.77 & 0.21 & 3.64 \\
\hline
\end{tabular}

Source: the work of authors based on available dataset across Romanian counties

(NUTS 3) [20]

According to results in Table no. 9, economic and infrastructural capital are positively associated with economic growth. Their estimated coefficients are statistically significant. There is no evidence of the impact of institutional and human capital on economic growth. Interestingly, social capital has a negative impact on economic growth, which is intuitively considering that this concept incorporates indicator variables representing costs such as social benefits. To conclude:

- Hypothesis 2: 'There is a positive and statistical significant relationship between territorial capital and economic growth' is confirmed only for two components of territorial capital: economic and infrastructural capital. 
Anca Dodescu, Elena-Aurelia Botezat, Alexandru Costăngioară, Marcel-Ioan Bolos

This research, unlike previous studies [5-7, 10, 14, 22], reveals that not all the components of the Romanian territorial capital positively influenced economic growth. Our results document:

1. a positive impact of economic and infrastructural capital on economic growth;

2. a negative impact of social capital on economic growth;

3. an insignificant impact of human capital and institutional capital on economic growth.

Thus we see that, from the economic growth perspective, it would be more efficient if funds would be directed towards active measures on labor market (reconversion, professional training, self-employment and inclusive entrepreneurship support and other measures aimed at increasing absorption of the unemployed by the labor market).

Analysis of the factors determining territorial capital reveals a relatively homogenous distribution of economic, infrastructural, institutional and human capital at national level. Consequently, the accumulation of territorial capital in Romania was determined equally by economic, infrastructural, institutional and cultural capital. The link between economic and infrastructural capital, on one hand, human and institutional capital, on the other hand, reveals that the chance for accumulating territorial capital can be improved by adequate public policies supporting the institutional infrastructure of cultural, health and education establishments and the professionals working in those institutions.

However social capital is negatively correlated with territorial capital. This can be explained by including in its composition indicator variables representing costs such as `social benefits' and 'unemployment recipients'. It is necessary that future research will analyze if this negative association persists after collecting data on additional indicator variables measuring social capital. In this respect, existing literature in the field suggests indicators such as `number of people paying taxes per 1000 people`, ‘number of economic crimes per one company` or `Hoover index [14]. Yet, since the RNIS does not provide such information [20], future research would have to be conducted to find solutions to this problem.

At this point, we should mention the difficulties we have encountered in gathering data. This is one of the reasons that limits the scope of our research. Thus, while Jona's approach (2015) [14] takes into account 7 components of territorial capital, we have found data for only 5 components. For relational capital (includes 
An Exploratory Analysis of the Territorial Capital and Economic Growth: Evidence from Romania

the communicational devices) and cultural capital (includes a number of different cultural institutions and their capacity) there is no data available in Romania's official statistical publications. Furthermore, for infrastructural capital we have found only 4 indicators; important indicators such as 'footpath and pavement per 1 $\mathrm{km} 2$ ', 'cycle path per $1 \mathrm{~km} 2$ ' or 'size of total green area', are missing. During the course of our research, especially when it comes to social capital, we have been confronted with the non-existence of an alternative source of data pertaining to volunteering, the involvement of individuals in civic actions, the number of NGOs etc. Hence, yet another limit imposed on our research.

\section{Conclusions}

The model of territorial capital, as literature review shows, can adequately explain economic performance of territories and provides a solid theoretical framework for sustainable development policy. Following the theoretical framework proposed by Camagni (2008, 2009) [6,7] and Jona (2015) [14], available data across Romanian counties (NUTS 3) offered by national statistics [20] allows for identifying five components of Romanian territorial capital: economic, infrastructural, institutional, human and social capital. The relationship between them and economic growth was investigated using the structural equation modeling methodology (SEM). Our research reveals that four components - economic, infrastructural, institutional and human capital - are contributing positively to the Romanian territorial capital and one - social capital - has a negative and statistically significant impact. The largest contribution on territorial capital is provided, in order, by institutional capital, human capital and economic capital. Data reveals that while social capital has a negative impact on economic growth, human and institutional capital fail to contribute to economic growth.

These results have important development policy implications, urging for investment in active measures on labor market. Nevertheless, results show that at the national level the accumulation of territorial capital can be sustainable, building upon the interactions between local economic units that cooperate in order to build competitive advantage and to create value for the society.

The present research is only the first step towards a more comprehensive analysis of the relationship between Romanian territorial capital factors and economic growth. The results are encouraging with respect to the economic and 
Anca Dodescu, Elena-Aurelia Botezat, Alexandru Costăngioară, Marcel-Ioan Bolos

infrastructural capital but they lead to the conclusion that Romania is still struggling in the 'infrastructure trap' as a prerequisite for economic growth and a greater focus on Camagni's 'innovative cross' is needed in Romania's development policy. Even if formulating an effective policy addressed to cooperation and relationality is extremely difficult for policymakers at local level in disadvantaged regions, which have a low attractiveness for SMEs and new technologies, such as Romanian regions [12], and mechanisms, relationships and networks that stimulate the necessary level of social capital, optimal institutional density and cumulative learning processes are almost impossible to implement from the outside, as Camagni (2009) [7] shows, the emancipation of development policy with the objective of 'preparing territories for innovation' [8] can't be bypassed anymore in Romania.

Future research is needed to address the relational and cultural capital and effectiveness of Romanian development policy. For an in-depth analysis, more indicators and alternative source of data would have to be available to evaluate the relationship between different Romanian territorial capital factors, especially intangibles, and economic growth. Also, related with other Romanian studies and our previous research in the field $[2,3,12]$, other research methods could be applied to overcome the limits of current research.

\section{REFERENCES}

[1] Albu, M. (1998), Construirea si utilizarea testelor psihologice (Construction and Use of Psychological Tests). Clusium: Cluj- Napoca, Romania;

[2] Bogdan,V.; Popa Sabău, C. D.; Belenesi, M.; Burja,V.; Popa, D. (2017), Empirical Analysis of Intellectual Capital Disclosure and Financial Performance - Romanian Evidence; Economic Computation and Economic Cybernetics Studies and Research; ASE Publishing; 51(2), 125-144;

[3] Bolos, M. I.; Sabău, C. D.; Scarlat, E.; Bradea, I-Al.; Delcea, C. (2016), A Business Intelligence Instrument for Detection and Mitigation of Risks Related to Projects Financed from Structural Funds; Economic Computation and Economic Cybernetics Studies and Research, 50(2), 165-178;

[4] Böhme, K.; Doucet, Ph.; Komornicki, T.; Zaucha, J.; Świątek, D. (2011), How to Strengthen the Territorial Dimension of 'Europe 2020' and the EU Cohesion Policy. Report based on the Territorial Agenda 2020 prepared at the request of the Polish Presidency of the Council of the European Union, Warsaw, Poland. Available online: 
An Exploratory Analysis of the Territorial Capital and Economic Growth: Evidence from Romania

\footnotetext{
http://www.mrr.gov.pl/rozwoj_regionalny/Prezydencja/Documents/Backgroun d report territorial dimension of EU2020 CP.pdf (accessed on 22 July 2016);
}

[5] Brasili, C.; Saguatti, A.; Benni, F. (2012), The Impact of the Economic Crisis on the Territorial Capital of Italian Regions. ERSA Conference, Las Vegas, Nevada, USA, 16-19 July 2012. Available online: http://www-sre.wu.ac.at/ersa/ersaconfs/ersa12/e120821aFinal00646.pdf (accessed on 24 September 2016);

[6] Camagni, R. (2008), Regional Competitiveness: Towards a Theory of Territorial Capital. Modelling regional scenarios for the enlarged Europe: European competitiveness and global strategies. Capello, R., Camagni, R., Chizzolini, P., Frasati, R. (Eds.). Springer-Verlag: Berlin, Germany;

[7] Camagni, R. (2009), Territorial Capital and Regional Development. Handbook of Regional Growth and Development Theories. Capello, R., Nijkamp, P. (Eds.). Edward Elgar: Cheltenham, UK;

[8] Camagni, R.; Capello, R. (2010), Macroeconomic and Territorial Policies Regional Competitiveness: An EU Perspective. Regional Science Policy \& Practice, 2, 1-19;

[9] Capello, R. (2007), A Forecasting Territorial Model of Regional Growth: The MASST Model. Annals of Regional Science, 41, 753-787;

[10] Capello, R.; Caragliu, A.; Nijkamp, P. (2009), Territorial Capital and Regional Growth: Increasing Returns in Cognitive Knowledge Use. Tinbergen Institute Discussion Paper, 59. Available at: http://papers.tinbergen.nl/09059.pdf (accessed on 24 September 2016);

[11] Capello, R.; Nijkamp, P. (Eds.). (2009), Handbook of Regional Growth and Development Theories. Edward Elgar: Cheltenham, UK;

[12] Dodescu, A. (2013), Economic Policies for Regional Growth and Development. Challenges for Romania in the Context of the Economic-Financial Crisis and Integration in the European Model. Romanian Academy, National Institute of Economic Research "Costin C. Kiriţescu" (Ed.), Expert Publishing House: Bucharest, Romania;

[13] Dunn, S.C.; Seaker, R.F.; Waller, M.A. (1994), Latent Variables in Business Logistics Research: Scale Development and Validation. Journal of Marketing, 15, 145-69;

[14] Jona, G. (2015), Determinants of Hungarian Sub-Regions' Territorial Capital. European Spatial Research Policy, 22, 101-119. Available online: http://www.academia.edu/13333094/DETERMINANTS_OF_HUNGARIAN_ SUB-REGIONS_TERRITORIAL_CAPITAL (accessed on 30 June 2015);

[15] Jöreskog, K. G. (1972), A General Method for Estimating a Linear Structural Equation System. Structural Equation Models in the Social Sciences. Goldberger, A. S.; Duncan, O. D. (Eds.). Academic Press: New York, USA; 
Anca Dodescu, Elena-Aurelia Botezat, Alexandru Costăngioară, Marcel-Ioan Bolos

[16] Keesling, J. W. (1972), Maximum Likelihood Approaches to Causal Analysis; $\mathrm{PhD}$ thesis, University of Chicago;

[17] Marsh, H.W; Hau, K.-T.; Wen, Z. (2004), In Search of Golden Rules. In Search of Golden Rules: Comment on Hypothesis Testing Approaches to Setting Cutoff Values for Fit Indexes and Dangers in Over Generalizing $\mathrm{Hu}$ \& Bentler's (1999) Findings. Structural Equation Modeling, 11(3), 320-341;

[18] McDonald, R.P.; Ringo Ho, M.-H. (2002), Principles and Practice in Reporting Structural Equation Analyses. Psychological Methods, 7(1), 64-82;

[19] Organisation for Economic Co-operation and Development (OECD). (2001), OECD Territorial Outlook. OECD Publishing: Paris, France;

[20] Romanian National Institute of Statistics (RNIS) (2015). Statistica teritorială. Repere economice si sociale regionale (Territorial Statistics. Regional Economic and Social Highlights). RNIS Publishing: Bucharest, Romania;

[21] Sechi, G.; Borri, D.; De Lucia, C.; Skilters, J. (2012), Trust and Economic Wealth in Regional Communities: Evidence from Latvia. Plurimondi, 10, 49-64;

[22] Servillo, L.; Atkinson, R.; Russo, A. P. (2011), Territorial Attractiveness in EU Urban and Spatial Policy: A Critical Review and Future Research Agenda. European Urban and Regional Studies, 19, 349-365;

[23] Wiley, D. E. (1972), The Identification Problem for Structural Equation Models with Unmeasured Variables. Structural Equation Models in the Social Sciences. Goldberger, A. S.; Duncan, O. D. (Eds.). Academic Press: New York, USA;

[24] Wright, S. (1934), The Method of Path Coefficients. Annals of Mathematical Statistics, 5 (3), 161-215;

[25] Yung, Y. F. (2010), Introduction to Structural Equation Modeling Using the CALIS Procedure in SAS/STAT Software. Available online: http://support.sas.com/rnd/app/stat/papers/JSM2010_Yung.pdf (accessed on Accessed on 01 March 2017). 